\title{
FAITH EMBODIED IN ATTITUDES: ETHICS OF DIALOGUE AND BROTHERHOOD OF ALL PEOPLE IN THE 'DOCUMENT ON HUMAN FRATERNITY FOR WORLD PEACE AND LIVING TOGETHER' IN ABU DHABI AND THE ENCYCLICAL FRATELLI TUTTI ${ }^{1}$
}

DENISA ČERVENKOVÁ,PETR VIZINA

\begin{abstract}
This text is concerned with the ethical approach of inter-faith relations and the dialogue of culture in two documents of Pope Francis: 'On Human Fraternity for World Peace and Living Together' and the encyclical Fratelli Tutti. This ethical approach refers to God the Creator of all and the call to brotherhood of all human beings and refers to faith as a response to Revelation. Faith also forms ethical approaches for interreligious dialogue. Pope Francis' approach in the documents is that the theological truth and values of religious traditions are embodied in attitudes of social friendship. Francis challenges us to build a specific environment that he calls a 'new culture of dialogue', having frequently called for the growth of a culture of encounter that is capable of transcending political and social barriers and encourages creating a specific culture of social and 'political love'.
\end{abstract}

\section{Keywords}

Pope Francis; Interreligious dialogue; Ethics of dialogue; Dialogue of cultures; Fraternity; Theology of religions; Fratelli tutti; Document on Human Fraternity

DOI: 10.14712/23363398.2021.4

Before approaching the topic of the ethical principles of inter-faith dialogue in the 'Document on Human Fraternity for World Peace and Living Together'² and the dialogue of cultures in Fratelli

\footnotetext{
1 This work has been supported by Charles University Research Centre programme No. 204052.

2 See Pope Francis and Ahmad Al-Tayyeb, 'Document on Human Fraternity for World Peace and Living Together' (4th February 2019), available at https://bit.ly/3hyvw78, accessed 4 March 2021. Further referenced as 'Pope Francis and Ahmad Al-Tayyeb:
} 
Tutti, ${ }^{3}$ let us remember the basic framework and purpose/aim of these documents. The first document, 'On Human Fraternity for World Peace and Living Together', focuses on the strategies and values in the inter-faith dialogue between Christians and Muslims. The second, the encyclical Fratelli Tutti is concerned with social dialogue in a broader sense, in the individual, political, and economic contexts. This ethical approach has a strong theological foundation. The foundation refers to God the Creator of all and the call to brotherhood of all human beings. Faith as a response to Revelation forms concrete ethical attitudes and approaches. The interconnection between faith and ethics is crucial in the hermeneutics of both documents of Pope Francis, especially understanding his ethics of brotherhood which is not primarily a social but a theological category. Francis' strategy of dialogue does not give up on the idea of the absolute horizon of truth in God's Revelation; however, the theological truth is embodied in attitudes that refer to the absolute horizon.

At the outset, the 'Document on Human Fraternity for World Peace and Living Together' refers to a shared theological foundation, a faith in God the Creator of everything and all people. This 'transcendental value' represents the foundation of common speech and a starting point for the negotiations between the representatives of the Holy See and the scholars of Al-Azhar Mosque, between Pope Francis and the imam Muhammad Al-Tayyeb.

The main topic of the discussions and the resulting document is the relationship of the religions and cultures, Christianity and Islam, often interpreted after the historical events of 11 September 2001 as a conflict. The religious foundation of the dialogue presupposes that a mutual relationship between humans, who are created by the one Creator, is the basis of fundamental equality between people.

Faith leads a believer to see in the other a brother or sister to be supported and loved. Through faith in God, who has created the universe, creatures and all human beings (equal on account of his mercy), believers are called to express this human fraternity by safeguarding creation and the entire

Document' with the article number. Due to the restrictions during the pandemic this text will refer predominantly to digital sources.

3 See Pope Francis, Fratelli tutti: Encyclical letter on Fraternity and Social Friendship, available at https://bit.ly/3hzisP3, accessed 20 January 2021. Further referenced as FT with the article number. 
universe and supporting all persons, especially the poorest and those most in need. ${ }^{4}$

The definition of brotherhood is based on the notion that since God created people equal in rights, duties, and dignity, all people are also called equally to common relationships of brotherhood so to share values of goodness, love, and peace. These general categories of values are later on in the document made more specific by notions of what is antagonistic in relationships, i.e., the reference to God's command not to kill other human beings but on the contrary to support the poor, those in need, and the marginalised. Signing the document with the Pope, the Muslim representative explicitly identified with the culture of dialogue, mutual collaboration, and knowledge as a way to act and a method for brotherhood to take place.

So, the value of human brotherhood has a theological basis. Brotherhood itself becomes a source of other values creating human society according to God's plan. This theological perspective creates efforts to meet and have a dialogue. The document itself is an outcome of brotherly meetings between Christians and Muslims, aiming to support and build a culture of mutual respect. This is possible for those of deep faith in God, believing that we are brothers and sisters.

The document seeks 'mutual understanding as a method and a standard' and looks for understanding in practical matters, finding parallels in the issues of maintaining peace, the importance of family as a 'fundamental nucleus of society and essential in bringing children into the world, raising them, educating them, and providing them with solid moral formation and domestic security.${ }^{5}$ It also seeks preserving personal freedom in faith, thinking, expressions, and actions, as well as female rights not to be second rate citizens and believers, and preserving the plurality of religion as God-given in his wisdom. Emphasis is on rejecting terrorism as a blind fanaticism that takes faith as a hostage. The matter in political abuse of religion is an image of God. We are not created by God to make wars, torture, and humiliate each other. ${ }^{6}$

Therefore, when the second document of Pope Francis, the encyclical Fratelli tutti speaks about the truth, it is not aiming to compare

\footnotetext{
Pope Francis and Ahmad Al-Tayyeb: Document, Introduction.

Ibid.
}

6 Ibid. 
different philosophical and theological concepts of truth (i.e., coherence, pragmatic, or the correspondence theory of truth). The aim of the document is not an abstract definition but practical consequences of true teaching to ethical concerns. ${ }^{7}$ Speaking of truth in the context of religion, the document is a reminder that both religious traditions are convinced that true teaching values peace, getting to know each other, and peaceful coexistence. Pope Francis explicitly mentions Francis of Assisi on a pilgrimage with a similar mission:

There is an episode in the life of Saint Francis that shows his openness of heart, which knew no bounds and transcended differences of origin, nationality, colour or religion. It was his visit to Sultan Malik-el-Kamil, in Egypt, which entailed considerable hardship, given Francis' poverty, his scarce resources, the great distances to be traveled and their differences of language, culture and religion. That journey, undertaken at the time of the Crusades, further demonstrated the breadth and grandeur of his love, which sought to embrace everyone. Francis' fidelity to his Lord was commensurate with his love for his brothers and sisters. ${ }^{8}$

\section{Theological Fundaments of Inter-Faith Dialogue}

The document from Abu Dhabi speaks of a God-given plurality of religious traditions. Surely, that is not an implication of the philosophical reasoning that either knowingly or unknowingly makes religious truths relative. As Christians, we do not find agreement with Muslims in arguments such as the unique and fundamental Christian experience of the Triune God and Jesus Christ's role in salvation. Does this document pose a threat to the fundamental identity of Christian faith? We dare say that from the point of the worries formulated in Dominus Iesus, it is not the case. Both faiths are firm in their fundamental presentation of religious experience. No consequences formulated in the

7 See Domenico Marafioti, 'Documento sulla Fratellanza umana. Una lettura raggionata,' Rassegna della teologie 60, no. 2 (2019): 243-246; Miguel Ángel Ayuso Guixot, 'Prophetic Meaning of the Document on Human Fraternity,' The Pontifical Councilfor Interreligious Dialogue, last modified 26 March 2019, accessed 20 April 2021, https:// bit.ly/3hwNerF.

8 FT 3. Pope Francis is certainly not doing pioneering work here. For the history of a dialogue with Muslims, see the aforementioned Domenico Marafioti ('Documento sulla Fratellanza umana,' 236-238). Ethical accents in dialogue are also characteristic for theologians as Hans Küng or K.J. Kuschel. 
document Dominus Iesus as results of acceptance of religious plurality apply to the dialogue between Islam and Christianity. There is no trace of indifferentism or relativism in the 'Document on Human Fraternity for World Peace and Living Together' from Abu Dhabi. There is no assumption that both religions 'are alike', which is the notion Dominus Iesus disapproves of.

The roots of these problems are to be found in certain presuppositions of both a philosophical and theological nature, which hinder the understanding and acceptance of the revealed truth. Some of these can be mentioned: the conviction of the elusiveness and inexpressibility of divine truth, even by Christian Revelation; relativistic attitudes toward truth itself, according to which what is true for some would not be true for others. ${ }^{9}$

Facing many reservations from both religious traditions, the document is knowingly a manual for religious practice. Expression of faith is supposed to support relationships among people. Both texts, the document from Abu Dhabi and also Fratelli tutti, which from now on will be more in the focus of this text, claim that faith should support human life's dignity, spiritual, human, and social values. Both texts are clearly rejecting not just religious but any form of terrorism.

It could be argued that the ideals in the documents are too high. ${ }^{10}$ However, looking closely at the theological background of both traditions, Christian and Muslim, it should be noted that the ethical ideal is in agreement with the main features of the religious faith of both traditions engaged in the dialogue.

Both documents anticipate that the 'culture of encounter' leads to wisdom, justice, and love. ${ }^{11}$ True relations are able to awaken the desire for faith in new generations, saving them from a materialistic mind

9 'On the basis of such presuppositions, which may evince different nuances, certain theological proposals are developed "at times presented as assertions, and at times as hypotheses" in which Christian revelation and the mystery of Jesus Christ and the Church lose their character of absolute truth and salvific universality, or at least shadows of doubt and uncertainty are cast upon them'. Congregation for the Doctrine of the Faith, Dominus Iesus. On The Unicity and Salvific Universality of Jesus Christ and the Church, 4, in Acta Apostolicae Sedis. Commentarium officiale, 2000, p. 745 .

10 For example, in passages of Pope Francis and Ahmad Al-Tayyeb: Document: L'Osservatore Romano, 4-5 February 2019, 6.

11 See, for example, FT 213. 
and from the logic of the survival of the fittest that sometimes has been substituted for the power of the law. ${ }^{12}$

Both documents hold up freedom of thought, speech, and action. Fratelli tutti explicitly states the idea that freedom of thought and acting is not just rooted in social agreement; it is a reference to God's intention. ${ }^{13}$ Going back to the sensitive issue mentioned at the beginning of the document, apparently, the idea of religious pluralism as a legitimate phenomenon might pose a problem not just for Muslims. Also, for some streams in the Catholic world, this grounding of religious plurality as a part of God's plan seems difficult to accept and not to see as contradictory to some magisterial texts. Religious pluralism de iure is most vividly under vocal criticism in the document Dominus Iesus. The document deals with the risks of relativist approaches of religious plurality as a threat to the call of the Church for mission.

However, in this instance, the idea of religious pluralism appears in a completely different context. We are not in the field of general philosophical-theological hypothesis penned by specific theologians but in the space of a concrete dialogue of two prominent faith figures with a clearly defined goal which is not a theological debate but a dialogue about the possibilities of coexistence.

In the context of Christian reflection, the encyclical Fratelli tutti could be seen as part of the theological lineage of Vatican II with an inclusivist approach in considering the salvation of those who follow other religions. ${ }^{14}$ Such an approach is rooted in the assumption that God's salvation initiative took place once and for all in Jesus Christ, and it includes all that is right and good in other religions. ${ }^{15}$

In Fratelli tutti, the ethics of dialogue and brotherhood especially is connected to understanding Revelation as a communication and a dialogue as it was defined in Vatican II. ${ }^{16}$ Transcendental reality enters history, revealing itself to humanity in the history of salvation. ${ }^{17}$ The

\footnotetext{
See FT 275.

See FT 211-214.

14 See the interfaith study in Denisa Červenková, Katolický pohled na náboženskou pluralitu (Praha: Karolinum 2016), 87-125, see also Giacomo Canobbio, Nessuna salvezza fuori della Chiesa? Storia e senso di un controverso principio teologico (Brescia: Queriniana, 2009); Claude Geffré, De Babel à Pentecôte: essais de théologie interreligieuse (Paris: Editions du Cerf, 2006).

15 See Denisa Červenková, Náboženství jako teologický fenomén (Červený Kostelec, Nakladatelství Pavel Mervart, 2013), 100.

16 See Dei Verbum 2.

17 See Červenková, Katolický pohled, 77.
} 
Christological and trinitarian hermeneutics of religious pluralism upholds a personal character of the truth and a relational perspective built on Christological foundations. The event of Christ created a command of positive acceptance of The Other or the difference of others in theology. ${ }^{18}$ The Mystery of the Trinity is an example for us constantly reaching the Other, with the crowning paradigm of the crucified and resurrected Christ penetrating the depth of human reality, breaking the barriers between God and human beings. From this radically relational perspective, a question of truth may be posed since, for Christians, truth is the person of Jesus Christ. ${ }^{19}$

Parallels can be found between both documents of the current pontificate and the encyclical Redemptoris Missio of the late Pope John Paul II, where he speaks of creating a just and brotherly community of dialogue. ${ }^{20}$ According to the encyclical, in inter-faith dialogue,

a vast field lies open to dialogue, which can assume many forms and expressions: from exchanges between experts in religious traditions or official representatives of those traditions to cooperation for integral development and the safeguarding of religious values; and from a sharing of their respective spiritual experiences to the so-called 'dialogue of life,' through which believers of different religions bear witness before each other in daily life to their own human and spiritual values, and help each other to live according to those values in order to build a more just and fraternal society. ${ }^{21}$

From this perspective, the ethics of brotherhood developed by Pope Francis is advancing three of the four fundamental elements of the dialogue (a dialogue of life, cooperation, and religious experience) which the document Redemptoris Missio speaks about.

Therefore, the ethics of brotherhood has its theological foundation in a certain approach to a Christian mission, referring to the experience of God's people with God's Revelation. St Francis is an example of such principle: a medieval saint on his journey to the Sultan of Egypt, Francis was capable of transcending the differences of origin, nationalities,

18 See Piero Coda, Il logos e il nulla. Trinità, religioni, mistica (Roma: Città Nuova, 2003), 137.

19 See Červenková, Katolický pohled, 153.

20 See John Paul II, Redemptoris Missio 57. L'Osservatore Romano, 23 January 1991.

21 See ibid. 
religion, making an enormous effort to define a position that is not in denial of their own identity. The aim was to share God's love, facing cultural and religious differences. ${ }^{22}$ The Frattelli tutti encyclical seems implicitly to refer to the fundamental Triunal missio of the Church God the Father sent his Son and The Spirit for a purpose: that believers might be able to live in relationships of brotherhood and sisterhood. ${ }^{23}$ Only from this theological fundament of the Church's missio can the social and political consequences be drawn. ${ }^{24}$

Similarly, another layer of the theological foundation of Fratelli tutti is a reference to God the Creator of mankind, calling us to a brotherly community of all. At the very outset of the encyclical, Pope Francis returns to the formulation from the document from Abu Dhabi: 'God has created all human beings equal in rights, duties and dignity, and has called them to live together as brothers and sisters. ${ }^{25}$ The encyclical focuses on the universal dimension of brotherly love and its openness to all. The style of expression and argumentation is, however, accommodated to people of good will ${ }^{26}$ so it is not only believers who can understand and be inspired. Fratelli tutti, as in all the papal documents, has first of all a theological basis. It is the trinitarian faith in God's missio: God is sending his Son and the Spirit so that people are able to live in the brotherly relationship St Francis spoke about. Only on this basis is it possible to speak about the social and political consequences of brotherhood. ${ }^{27}$

\section{Relationship Ethics of Brotherhood}

Both texts, the Abu Dhabi document and the encyclical Fratelli $t u t t i$, have social and, therefore, political implications, albeit without mentioning specific political movements or dealing with politics in an

\footnotetext{
See FT 3.

23 For the Triune fundament in the Church mission see Pavol Bargár, 'Koncepcie teológie relevantné pre súčasnú dobu vo významných misiologických dielach,'Acta missiologica 10, no. 2 (2016): 9-16.

24 See Fabio Colagrande, 'Fratelli tutti, Forte: traduce il Vangelo per il mondo di oggi,' accessed 28 January 2021, https://bit.ly/3kdurn5; see also David J. Bosch, Dynamika krestanskej misie (Praha: Středoevropské centrum misijních studií, 2009), 10; Denisa Červenková, Etika mezináboženského a mezikulturního dialogu (Praha: Karolinum, 2018), 58-59.

25 FT 5.

26 FT 6.

27 Colagrande, 'Fabio, Fratelli tutti.'
} 
organisational sense..$^{28}$ Both texts are political in a broader sense of the word, understanding humans as social beings who are political from their very nature. ${ }^{29}$

The ethos of human brotherhood is not entirely new idea. The Universal Declaration of Human Rights $(1948)^{30}$ states equality of people: 'All human beings are born free and equal in dignity and rights. They are endowed with reason and conscience and should act towards one another in a spirit of brotherhood.' The Declaration also points out that society is needed for each individual to achieve their full growth. The society is to respect and keep the rights of individuals. Individuals are obliged with duty to their societies. 'Everyone has duties to the community in which alone the free and full development of his personality is possible. ${ }^{51}$ Societies differ in their understanding of duties according to their culture and political and spiritual traditions. Therefore, they are as a human family 'destined' to dialogue and called to acceptance of differences on the basis of mutual relationship.

The chapter called 'Dark Clouds over a Closed World'32 in Fratelli tutti describes some aspects straining the development of brotherhood - even with the experience of wars, we have not learned to live a brotherly life. Old conflicts masked as a defence of national interest return, 'myopic, extremist, resentful and aggressive nationalism are on the rise'. ${ }^{35}$ Among 'new forms of cultural colonialism', the Pope lists preferring individual interests over the community dimension of human existence and growing dependency of poor and weaker regions on strong countries. The Pope talks about a growing loss of the sense of history, looking down on the past, of the human and spiritual richness of previous generations. We become people uprooted, without trust,

28 However, it is quite clear from Fratelli tutti that criticism of 'economic powers that demand quick profits' (17) or about 'temptation to build a culture of walls, to raise walls, walls in the heart, walls on the land, in order to prevent this encounter with other cultures, with other people,' Francis, albeit indirectly points out to the hegemon power of the USA. In the past, Francis made clear that he sees being Christian and building a wall as contradictory. See the Pope's comments on Donald Trump in 2016 in 'Donald Trump's Christianity questioned by Pope Francis,' BBC News, last modified 18th February 2016, https://www.bbc.com/news/av/world-35607538.

33 FT 11. 
easily falling prey to ideologies. ${ }^{34}$ Those that 'abandon their tradition and allow others to rob their very soul' in order to mimic and copy a stronger culture 'end up losing not only their spiritual identity but also their moral consistency and, in the end, their intellectual, economic and political independence'. ${ }^{35}$

Brotherhood is also weakened by spreading despair and discouragement, even under the guise of defending traditional values, employing a strategy of ridicule, suspicion, and relentless criticism; in a variety of ways, one denies the right of others to exist or to have an opinion. Their share of the truth and their values are rejected, and as a result, the life of society is impoverished. ${ }^{36}$ We find ourselves in the times of 'everybody against everybody' when it is all the more difficult to perceive another being as a fellow human, a neighbour in need. ${ }^{37}$ Some members of humankind: the poor, the disabled, unborn children, the elderly, we are able to 'throw away'. Our obsession with cost reduction results in unemployment even when we know that 'some economic rules have proved effective for growth, but not for integral human development. ${ }^{38}$

In such conditions, the search for cooperation for justice and peace seems an outdated utopia. ${ }^{39}$ The encyclical mentions the Covid-19 pandemic as a reminder of a problem that no government can solve alone. ${ }^{40}$ The pain, uncertainty, fear, knowing our limits that the pandemic took to the fore - all challenges our lifestyles, relationships, organisation of society, and the meaning of human existence.

Christological justification of the position that is introduced as the basis of human relationships can be recognised in the topic of migration: the relationship with the foreigner is built on the capability of 'recognizing Christ's face in the other'41 because 'a believer has the chance to recognize that God loves every human being with endless love'. This love was manifested in Christ and his salvation sacrifice

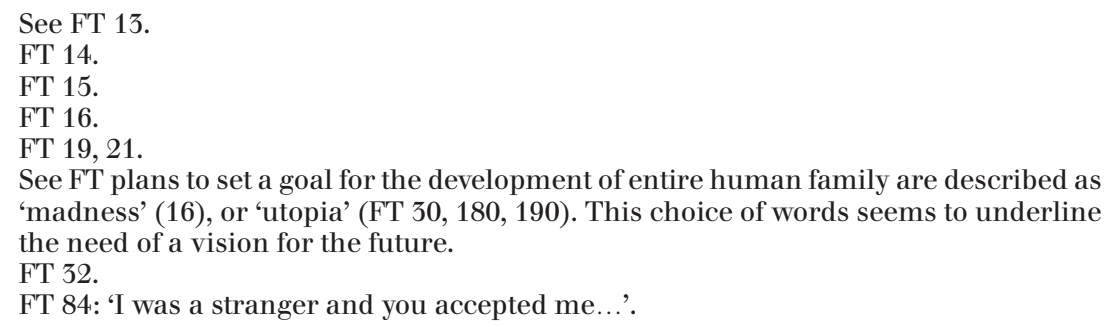


for every human, 'we believe that Christ shed his blood for each of us and that no one is beyond the scope of his universal love'. ${ }^{42}$ The mentality of xenophobia and closedness are incompatible with Christianity; human dignity is more important than origin, skin colour, or religion. Human dignity is the legge suprema of brotherly love. ${ }^{43}$ Violence, nationalism, xenophobia, contempt, and oppression are, from the point of view of Christianity, unacceptable forms of relationships between humans. ${ }^{44}$

The biblical and theological fundamental of brotherhood builds on the foundational characteristics of God in Jewish-Christian tradition: our experience shows God as the merciful Father and Creator of all. We are called to act like God: to have mercy on everyone ('man has mercy over neighbour, but God has mercy for all his creatures'), he is merciful to all, ('be merciful as your Father is'). There are no specifications in the category of 'neighbour', be it ethnic or national, because the category points to the father of all people. The goal of human life is also understood theologically (formulated in FT 68): we are created for fullness that can be attained only through love. In the language of Pope Francis, to love means to shift one's attention to the other person and appreciate how nice, beautiful, and dear the person is. The ability to focus on the other and not to leave them even when facing their pain, but on the contrary, to spend time and come closer to them is again more than solidarity. According to the encyclical, it is an expression of the Christian faith. In Fratelli tutti, brotherhood has a significantly Christological fundamental; we are to recognise 'Christ in each of our abandoned brothers and sisters'. It is through faith as the source of knowing God and his relationship with the world, 'for believers come to know that God loves every man and woman with infinite love'. A part of Christian faith is a strong belief that 'we believe that Christ shed his blood for each of us and that no one is beyond the scope of his universal love'.

\footnotetext{
FT 85.

FT 39.

44 According to FT it is sad that the Church took so long to denounce slavery and violence. It is for the development of theology and spirituality (i.e., not because of agreement in society or for some other reasons), there is no excuse for violence, etc.
} 


\section{A Dialogue in Society}

In Chapter 6, the encyclical returns to the topic of dialogue, which means 'approaching, speaking, listening, looking at, coming to know and understand one another, and to find common ground' ${ }^{45}$ Reason for the dialogue is to keep society together: 'What would our world be like without the patient dialogue of the many generous persons who keep families and communities together. Unlike disagreement and conflict, persistent and courageous dialogue does not make headlines, but quietly helps the world to live much better than we imagine. ${ }^{46}$

Dialogue in society is impossible unless we respect the other person's opinion, unless we recognise that their opinion consists of legitimate interests, and unless we believe that the other person has something to offer. The plurality of opinion may not be perceived as threatening:

When individuals or groups are consistent in their thinking, defend their values and convictions, and develop their arguments, this surely benefits society. Yet, this can only occur to the extent that there is genuine dialogue and openness to others. Indeed, 'in a true spirit of dialogue, we grow in our ability to grasp the significance of what others say and do, even if we cannot accept it as our own conviction. In this way, it becomes possible to be frank and open about our beliefs, while continuing to seek points of contact, and above all, to work and struggle together. ${ }^{47}$

In our opinion, the following topic of the relation between the plurality of opinion and values and the search of universal values and truthfulness is one of the key passages in the encyclical. A true dialogue, according to Francis, cannot be based on relativism that is convicted that there are no universal principles or objective truths. This kind of tolerance ultimately leaves the interpretation of moral values to those in power: 'When the culture itself is corrupt, and objective truth and universally valid principles are no longer upheld, then laws can only be seen as arbitrary impositions or obstacles to be avoided. ${ }^{94}$

On the contrary, Pope Francis claims it is possible to search for the truth that responds to our deepest convictions and gives meaning to

\footnotetext{
FT 198.

Ibid.

FT 203.

48 FT 206.
} 
our lives. Even laws have meaning when based on the conviction that 'each human being is sacred and inviolable'. ${ }^{49}$ The truth is defined as a firm foundation for human decisions and making laws. The truth is, according to Francis, connected with the recognition that 'the intellect can investigate the reality of things through reflection, experience and dialogue, and come to recognize in that reality, which transcends it, the basis of certain universal moral demands. ${ }^{50}$ In this respect, Pope Francis cites John Paul II in the encyclical letter Centesimus annus: 'If there is no transcendent truth, in obedience to which man achieves his full identity, then there is no sure principle for guaranteeing just relations between people. ${ }^{51}$

\section{Dialogue as a Means of Finding Permanent Values and Objective Truth}

However, is there a possibility of finding agreement in a pluralist society without resigning ourselves to the question of truth? The encyclical shows that any ephemeral agreement is not enough: 'in a pluralistic society, dialogue is the best way to realize what ought always to be affirmed and respected apart from any ephemeral consensus. ${ }^{92}$ Such a dialogue is to be built on rational arguments with a variety of perspectives and the contribution of different fields of knowledge and points of view. 'Nor can it exclude the conviction that it is possible to arrive at certain fundamental truths always to be upheld.' These enduring truths are to be always held by society: they are above all agreement and transcend our situational contexts. Our understanding of these values, their meaning and scope can increase, but in themselves, these truths are 'held to be enduring by virtue of their inherent meaning', Pope Francis states.

From values, we are moving towards the truth - values are not necessarily a goal of society's interests, social agreement, or objective truth: there is no need to perceive social convenience and objective truth as opposites. The Pope speaks about certain basic structures 'to support

\footnotetext{
FT 207.

FT 273.

51 John Paul II, Centessimus Annus (1st May 1991), 44. Acta Apostolicae Sedis, 83 (1991), 849, accessed 1 June 2021, https://bit.ly/3wzaQjK.

52 FT 211.
} 
our development and survival ${ }^{153}$ - there are enduring and robust ethical principles with their source in human nature. This nature was created by God; therefore, he is the basis. ${ }^{54}$

An example of truth that corresponds to human nature apart from all cultural change is respecting human dignity: people are worth more than things and circumstances, therefore cannot be apprehended as objects:

The dignity of others is to be respected in all circumstances, not because that dignity is something we have invented or imagined, but because human beings possess an intrinsic worth superior to that of material objects and contingent situations. This requires that they be treated differently. That every human being possesses an inalienable dignity is a truth that corresponds to human nature apart from all cultural change. ${ }^{55}$

Given this idea of the basis of our social interaction and culture of dialogue in enduring truth, we see that, in Fratelli tutti, the Pope approaches the reader out of the Jesus-like basis of brotherhood and personal character of truth. This truth is not at our disposal; we do not own it. On the contrary, we answer to this truth. By setting this truth, our goal leads to an ethical commitment to our neighbour.

For this message, the Pope chooses a radical Christocentric attitude as a starting point for the dialogue, showing that dialogue is not a threat to the identity of those engaged. On the contrary, dialogue presupposes an identity deeply rooted. Ethical aspects of Fratelli tutti reveal a strategy that does not give up on the idea of the absolute horizon of the truth in God's Revelation, yet instead of deducing the truths from Revelation the Pope chooses to look in the opposite direction - faith is embodied in attitudes that point to the absolute horizon of Revelation.

In Fratelli tutti, the Pope embodied his deeply rooted faith in values. The encyclical engages the reader, religious or secular alike, as a partner in a dialogue, inviting them to what might be a fruitful journey in

\footnotetext{
FT 212.

'As believers, we are convinced that human nature, as the source of ethical principles, was created by God, and that ultimately it is he who gives those principles their solid foundation. This does not result in an ethical rigidity nor does it lead to the imposition of any one moral system, since fundamental and universally valid moral principles can be embodied in different practical rules.' FT 214.

55 FT 213.
} 
search of fundamental truth and enduring values ${ }^{56}$ that anchor human dignity and social justice. The attitude creates a 'culture of dialogue' rooted deeper than in ephemeral agreement, in eternal values that, for Christians, are embodied in the story of Jesus Christ. ${ }^{57}$ In this sense, the Pope's attitude is both dialogical and missiological.

The value of truth and the meaning of truth as value is upheld and repeatedly stressed in Fratelli tutti. The overall concept is that the fact of the existence of humanity is in favour of 'objective' (transcendent) truth. As a first step, the existence of such truth is not to be $a$ priori excluded as nonsensical. Opposing relativism, Fratelli tutti points out that deeper truth and meaning is inherent to the very core of humanity:

Is it possible to be concerned for truth, to seek the truth that responds to life's deepest meaning? What is law without the conviction, born of age-old reflection and great wisdom, that each human being is sacred and inviolable? If society is to have a future, it must respect the truth of our human dignity and submit to that truth. Murder is not wrong simply because it is socially unacceptable and punished by law, but because of a deeper conviction. This is a non-negotiable truth attained by the use of reason and accepted in conscience. A society is noble and decent not least for its support of the pursuit of truth and its adherence to the most basic of truths. ${ }^{58}$

To a situation of corrosive politics of endless differentiating between 'us' and 'them', the Pope brings a message of 'political love'59 that views differences as God-given plurality. Engaging the imagination of the reader, Francis encourages working in a small scale yet with a larger

б6 FT 211.

57 See FT 277. The Pope adheres to the idea that God's is present in different religious traditions (as stated in the document Nostra Aetate). Yet the Pope strongly affirms the idea that Jesus Christ is the fundamental and unique source of values for Christians and the Gospel of Jesus Christ is the approval of human dignity and brotherhood of all people.

58 FT 207.

59 Pope Francis uses this rather unusual term consisting of two words from seemingly different vocabularies, public (political) and private (love), echoing the slogan 'Private is political' coined in late 1960s human rights movement. However, in Fratelli tutti this slogan seems to encourage thoughts on private vices (malice, hatred) that in the age of populism became political force. For more on Fratelli tutti as a political programme, see a paper by Prof Petr Kratochvíl from the Institute of International Relationships in Prague: Petr Kratochvíl, 'Foundation of Pope Francis' (Geo)political Programme, International Studies Association's Religion and International Relations Section,' last modified 14 December 2020, accessed 1 June 2021, https://bit.ly/3yNZ6LY. 
perspective of human society as a 'polyhedron, in which the value of each individual is respected, where "the whole is greater than the part, but it is also greater than the sum of its parts"". ${ }^{60}$

The model chosen from geometry illustrates the principle of appreciating differences in society. Yet another example of differences adding value to pluralist society in Fratelli tutti comes from Saint Irenaeus: 'One who seeks the truth should not concentrate on the differences between one note and another, thinking as if each was created separately and apart from the others; instead, he should realize that one and the same person composed the entire melody. ${ }^{91}$

Again, this appreciation of the differences that can create melody is not some shallow positive and sentimental outlook on reality. Rather, the Pope is realistic in describing the culture of 'comfortable consumerist isolation' that 'encourages remarkable hostility, insults, abuse, defamation and verbal violence destructive of others' ${ }^{62}$ Fratelli tutti makes sure the reader is being constantly reminded of the illusion of an individual with no ties to society and relationship with others. ${ }^{63}$

As already mentioned, Francis' idea of social and political life comes from Christian ethics of dialogue: being aware of one's own identity allows for not perceiving otherness as a threat; on the contrary, as a God-given difference, it allows others to be themselves and be different from us: 'Seeing ourselves from the perspective of another, of one who is different, we can better recognize our own unique features and those of our culture: its richness, its possibilities and its limitations. ${ }^{94}$

In both documents from Abu Dhabi and in the Fratelli tutti encyclical, there is no polishing or whitewashing the differences between the foundations of Christianity in the person of Jesus Christ and Islam in order to reach agreement. Both documents are reminders that values like truthfulness, justice, and mercy are common denominators pointing to the truth, being starting points from the current situation in which religion is often mentioned as a dividing force. In this sense, the values are not a compromise at the expense of truth claims, but they are called to serve a pragmatic goal, the goal of peaceful coexistence.

\footnotetext{
FT 145.

FT 58.

FT 44.

FT 44.

FT 147.
} 
This brings us back to the theological fundamentals of the Fratelli tutti encyclical: the secular basis, i.e., a declaration of equality and civic society, do not suffice for a claim to treat each other in a brotherly way. Citing Benedict XVI and John Paul II, the encyclical reminds us that the lasting fundamental principles of human relationships are impossible to be found without grounding them in transcendental truth: 'If there is no transcendental truth, in obedience to which man achieves his full identity, then there is no sure principle for guaranteeing just relations between people. ${ }^{65}$ Then, self-interests of classes, groups, or nations take place, setting people against each other. 'If one does not acknowledge transcendental truth, then the force of power takes over, and each person tends to make full use of the means at his disposal in order to impose his own interests or his own opinion, with no regard for the rights of others... ${ }^{96}$

\section{Faith Embodied in Attitudes: Ethics of the Good Samaritan}

We have summed up the main ethical approach in both texts being faith embodied in attitudes. A practical question arises: What reaction do the authors expect? How practically to achieve the attitudes of brotherhood and solidarity? The Pope portrays the reality lacking in both principles. The main ethical question arises here: What are we to do?

The three major categories of normative ethics (consequentialism emphasising the consequences of actions, Kantian deontology emphasising norms and rules, and virtue ethics based on virtues and moral character) in reality often blend or overlap or are complementary. ${ }^{67}$ However, in order to capture the main principle in the documents that warn against the divisive spirit, aggression, and destruction, we come to think that a change in the character of individuals and society is desirable to create the 'culture of dialogue', of 'political love'.

There is a hint at the beginning of Fratelli tutti pointing to the biblical source of the Pope's ethical approach demonstrated in both documents. ${ }^{68}$ The approach serves as an example of faith embodied in

\footnotetext{
FT 273.

FT 273.

${ }^{67}$ See Jef Van Gerwen, Origins of Christian Ethics in The Blackwell Companion of Christian Ethics, ed. William Schweiker (Oxford: Blackwell, 2005), 213.

68 There is a connection between the two documents. At the beginning of Fratelli tutti the Pope refers explicitly to the 'Document on Human Fraternity': 'Issues of human
} 
attitudes: 'A plan that would set great goals for the development of our entire human family nowadays sounds like madness. ${ }^{96}$

The Pope summarises his persistent effort of peaceful living of the entire human family in the word 'madness'. Further on, the text explains reasons for such a strong expression not commonly used in the official language of declarations and encyclicals. A poignant and realistic portrait of the society in the 21 st century shows growing estrangement between individuals and a failing effort to make the world less divided and more just. The word madness, in this sense, may point out the inequality of the means to reverse the trend. The concept of reason coming short, of madness or foolishness in this context might, in a document relying so often on biblical imagery, point in yet another direction: when the apostle Paul in the First Letter to the Corinthians defines his approach to the Gospel among Greek and Jewish culture and thinking, Paul coins the phrase 'foolishness' ( $\left.\mu \omega \rho^{\prime} \alpha\right)$ of the Cross. ${ }^{70}$

Paul addresses his message of 'foolishness' of the Cross to the Church in Corinth divided and disagreeable about whether to follow Paul, Apollos, Cephas, or Christ. The unusual term 'madness' in Fratelli tutti, therefore, might suggest that the same strategy that Paul uses in the divided Church in Corinth, Pope Francis suggests and plans on using in our divided world. What seems 'mad' is a reference to the humility and kenosis of Jesus Christ on the Cross as a fundament of strategy in the divided world of particular opinions.

The Pope, in this strategy of the 'madness' of the Cross, adopts the concepts that the modern world was built on freedom, equality, and

fraternity and social friendship have always been a concern of mine. In recent years, I have spoken of them repeatedly and in different settings. In this Encyclical, I have sought to bring together many of those statements and to situate them in a broader context of reflection. In the preparation of Laudato Si', I had a source of inspiration in my brother Bartholomew, the Orthodox Patriarch, who has spoken forcefully of our need to care for creation. In this case, I have felt particularly encouraged by the Grand Imam Ahmad Al-Tayyeb, with whom I met in Abu Dhabi, where we declared that "God has created all human beings equal in rights, duties and dignity, and has called them to live together as brothers and sisters." This was no mere diplomatic gesture, but a reflection born of dialogue and common commitment.' (5)

FT 16. In Pope Francis and Ahmad Al-Tayyeb: Document, family is often mentioned in the context of a basic cell in society, the place of moral education and safety, deserving respect, protection, and support. Pope Francis uses the wider term 'human family' 41 times in Fratelli tutti. 
the brotherhood of all people - and connects them again with their meaning. Embracing these concepts has its precedents especially in the documents of the Second Vatican Council. The novelty here is the Pope's radical emphasis on the ethics of brotherhood. The Pope's struggle to care for the polis is summarised here: the polis meaning the whole world and all people its legitimate citizens. As the Pope notes in Fratelli tutti, 'extremism and polarisation have become political tools. ${ }^{.71}$ Solidarity and mutual love in this sense can be considered political qualities and tools. Therefore, either directly or non-directly, we can speak, albeit unusually, of 'political love', which is even the name of one chapter in Fratelli tutti.

Differences in opinion about organising and leading society and values have become tools in the hands of populists. The social networks on the internet encourage and capitalise the users' inclination to controversy. There is an unlimited number of creating and dividing lines between 'us' and 'them'. The Pope addresses this principle as one of the reasons of the current growth of nationalism and repeatedly warns against this phenomenon recalling the inauspicious historical lessons with nationalism.

This might be a point where we can afford a sceptical approach coined at the beginning of Fratelli tutti as 'madness'. How can such trends be reversed? No less than a steady change in attitudes is asked for. This might be the reason why the parable of the Good Samaritan is the axial text in Fratelli tutti trying to attract our imagination and moral sense. The core of the parable is the Samaritan's attitude.

The parable in which a priest, a Levite, and a Samaritan come across a hurt man by the side of the road speaks to reality on a deeper level; when the Pope explains the inherent human dignity in Fratelli tutti, he implies that the reflection of reality and a real dialogue brings us to fundamental ethical principles:

For this reason, human beings have the same inviolable dignity in every age of history and no one can consider himself or herself authorized by particular situations to deny this conviction or to act against it. The intellect can investigate the reality of things through reflection, experience and dialogue, and come to recognize in that reality, which transcends it, the basis of certain universal moral demands. To agnostics, this foundation

71 FT 15. 
could prove sufficient to confer a solid and stable universal validity on basic and non-negotiable ethical principles that could serve to prevent further catastrophes. As believers, we are convinced that human nature, as the source of ethical principles, was created by God, and that ultimately it is he who gives those principles their solid foundation. ${ }^{72}$

The parable of the Good Samaritan uses the same logic, warning the reader against the knowledge (truths) about God yet abstracting from reality (and the neighbour beside the road). This is why the late German theologian Dorothee Soelle calls this parable 'an anti-fundamentalist one par excellence'. ${ }^{73}$ Warning against fundamentalism, political or religious, is the ethical heritage of both documents. When reading the parable, it is obviously very easy to identify with the Samaritan and, in this way, get ahead of the moral of the story. The moral is a constant examination of whether the truth about God becomes a reality in the relationship with the neighbour.

\section{Conclusion}

In his doctrine of faith, it is clear that the Pope does not diverge from his predecessors. Novelty is the radicality of his dialogical approach with which the Pope enters the debate with the reader, demonstrating the very attitude the reader is challenged to adopt. Francis is not entering the debate with clearly defined doctrinal truths, yet he is challenging the reader not to a priori exclude the possibility that absolute, eternal, and objective truths exist. The Pope shows that belief in the existence of objective truth is not necessarily contradictory to society's interest in finding agreement. In other words, Francis is inviting the reader to discover the world enlightened by the objective truth without putting himself into a position that identifies itself with the truth. He repeatedly warns against moral relativism in which particular opinions masked as 'truths' claim to be universal.

The key part is the Pope's belief in the transcendental dignity of each individual: that is, the 'religious basis of brotherhood'. Brotherhood built on the experience of God the Creator and Father of all is, from

2 FT 213, 214.

75 Quoted in Maureen Junker-Kenny, Approaches to Theological Ethics (London: T\&TClark, 2019), 94. 
the perspective of Christian theology, the only relevant possibility of discussing the category. According to Francis, this foundation can be offered even more generally.

Catholic Theological Faculty, Charles University Thákurova 3 16000 Praha 6 Czech Republic E-mail:Denisa.Cervenkova@ktf.cuni.cz E-mail: petr.vizina@email.cz 